\title{
Like Sands through the Hourglass: How to Develop a Good Legal Research Problem
}

Susan T. Phillips

Texas A\&M University School of Law, sphillips64@law.tamu.edu

Follow this and additional works at: https://scholarship.law.tamu.edu/facscholar

Part of the Law Commons

\section{Recommended Citation}

Susan T. Phillips, Like Sands through the Hourglass: How to Develop a Good Legal Research Problem, 28 Legal Reference Services Q. 219 (2009).

Available at: https://scholarship.law.tamu.edu/facscholar/145

This Article is brought to you for free and open access by Texas A\&M Law Scholarship. It has been accepted for inclusion in Faculty Scholarship by an authorized administrator of Texas A\&M Law Scholarship. For more information, please contact aretteen@law.tamu.edu. 


\title{
"Like Sands Through the Hourglass...": How to Develop a Good Legal Research Problem
}

\author{
SUSAN T. PHILLIPS \\ Texas Wesleyan University School of Law, Fort Worth, Texas, USA
}

\begin{abstract}
Attorneys have a duty to conduct adequate legal research. Law schools have an obligation to educate students in the standard research techniques. To learn research, students must actually perform research using research problems. Therefore, professors must design appropriate problems for students to learn research skills. The first part of this article discusses the fundamentals of developing a research problem. The second part provides examples of research problems with an explanation of their development.
\end{abstract}

KEYWORDS develop, legal, research, problem, question

"You may be guilty of legal malpractice if you do not conduct adequate legal research!" warns the legal research instructor/professor in an attempt to "scare straight" the novice researcher into paying attention to the day's lesson of Shepardizing, KeyCiting, digest searching, statute updating, or any other legal research task.

The professor's attention-getting statement is technically accuratecourts have recognized that an attorney may be liable for malpractice if the attorney fails to conduct adequate legal research when the issue is neither an unsettled nor debatable area of law. ${ }^{1}$

\section{DUT'Y TO RESEARCH}

But aside from intimidating students in their first weeks of law school, this statement emphasizes the importance of learning to conduct legal research. It indicates that learning to conduct legal research is as important as learning

Address correspondence to Susan T. Phillips, Texas Wesleyan University School of Law, 1515 Commerce Street, Fort Worth, TX 76102. E-mail: sphillips@law.txwes.edu 
the principles of consideration in a contract, negligence in torts, and the personal jurisdiction concepts of International Shoe. "A lawyer is expected to possess knowledge of those plain and elementary principles of law which are commonly known by well-informed attorneys and to discover those additional rules of law which, although not commonly known, may be readily found by standard research techniques." 3 As the court noted, legal research is as crucial to the practice of law as the principles of contracts, torts, and civil procedure.

Consequently, it is the duty of law schools to graduate students with not only knowledge from doctrinal classes but also with comprehension of the "standard research techniques" that all attorneys are expected to possess.

\section{RESEARCH THROUGH SIMULATION}

The teaching of legal research skills is typically included in the first-year program, usually in conjunction with legal writing or in an upper-level advanced legal research class. Whether the research class is a first-year course or upper-level course, the students must actually perform legal research to learn legal research. Students cannot learn and master how to conduct legal research by reading a legal research text. Nor can the student learn the skill by listening to an expert explain how to conduct legal research. Legal research is a skill that a student can only truly master by actually performing the research. In other words, legal research classes must be taught through simulation by the student actually performing the research task.

A simulation or skills class requires that the professor design research problems for the students to hone their skills. This article's goal is to aid the professor in developing a legal research problem that will be effective in teaching the student the "standard research techniques" needed for the practice of law. This article will specifically address the writing of a problem for teaching the tools and methodology of legal research. The first part focuses on the fundamentals of developing a research problem and the second part provides two examples of research problems with annotations explaining their development.

\section{FOCUS ON RESEARCH}

In many, if not most, first-year legal writing and research courses, the component of legal research is incidental to the legal writing. Instructors focus on the written work product to be produced by the law student and not on the components of legal research. For example, a writing instructor's goal is to have his or her students write a memorandum explaining a specific area of law for a particular jurisdiction, such as the law of holographic wills in 
Texas. The professor's main focus will be on teaching the student the components of the legal memo-the question presented, statement of the facts, brief answer, legal analysis, and conclusion, as well as proper grammar and citation. If the focus was on or included legal research, the professor would look to see whether the problem was teaching the students the fundamentals of the legal research process. For a statutory problem, the professor would write a problem that required the students to determine whether there was a relevant statute, whether the statute was updated, what cases interpreted the statute, and whether the cases were still good law through verification. The skill of legal research has its own uniqueness that is separate from the skill of legal writing. A student can conduct legal research without incorporating the results in a written work, just as a student can write a legal memorandum without personally completing the research. Consequently, it is imperative for a professor whose goal is teaching legal research to focus specifically on research.

Before the professor begins the actual writing of the research problem, he or she must first determine what the teaching outcome of the assignment will be. What tools or aspects of legal research are the most important for the students to learn in the given time period? The answer is that the professor must first equip the students with the basics of legal research. To determine these "basics," the professor should answer the question, "What are the research skills that every attorney is expected to possess?" Although open to debate, the core of the basics includes the following: case finding, case updating, statute finding, and statute updating. In a first-year class, a professor may also include secondary sources as part of the basics because these tools aid the students, particularly the novice, in not only finding both cases and statutes but also understanding the law. If time permits, the professor could also include locating and updating administrative rules, regulations, and decisions; finding practice and form material; finding court rules; and finding legislative history. Such decisions will depend on the number of classes the professor will have with the students and the amount of information that can be covered in that time period. For example, a professor can cover more information if teaching ten fifty-minute classes than if he is teaching six fifty-minute classes.

\section{TREASURE HUNT PROBLEMS}

The professor must also determine what type of problem he will be giving to the student. In teaching legal research, there are two different types of questions used for teaching legal research, the "treasure hunt" question and the contextual or process question. The first type, the treasure hunt question, asks the student to go look for the answer to a question. The end product focuses on the answer to the question without the student providing the 
steps as to how he found the answer. ${ }^{4}$ The question can be about the legal research tool itself (What states' cases are included in the Pacific Reporter?), about a feature of the primary authority (What is the name of the case found at 367 U.S. 643?), or about the law (What is the maximum fine permissible under 16 U.S.C. $\S 4307$ ?).

Typically, treasure hunt questions work well to acquaint students with the fundamental elements of legal research tools and resources-what the resources themselves look like, what the features of the resources are, and what the law in the resources looks like. Treasure hunt questions do not explicitly show the process of legal research or how to move through the steps of research. In other words, treasure hunt questions do not show the student how the research tools fit into the context of legal research, at least not in an obvious way. However, treasure hunt problems do have their place in teaching the student the fundamental tools of legal research as a foundation before moving into contextual problems.

To write a treasure hunt problem, the professor begins with the resource that the student will use to answer the question. The professor determines the answer that the student will need to find and writes the question to lead the student to that answer. By their very nature, the treasure hunt questions have answers. In developing these questions, the most important aspect is the question itself. The question should provide the student with enough information to find the answer. The author should include relevant keywords in the question that will lead the student to the answer. For example, if the question requires a student to use an index to find the answer, the indexing terms or a very close synonym should be provided in the question. The concept of giving the student the identical or near-identical terms in the question is particularly helpful the first time or two that a student conducts research in a particular resource. This method minimizes the student's frustration as he navigates the resource and permits him to concentrate on using the source instead of being frustrated by terms or keywords.

In addition, the question should eliminate any ambiguity by communicating to the student the specific answer that is required. If there are multiple answers to the question asked, the question should limit the student to the answer the professor is wanting. Does the professor want the student to supply all of the answers or just one specific answer? For example, the professor wants the student to use an index to find an article that discusses trademark parody. If he writes the question as, "Find a law review article whose subject is trademark parody," the student will find dozens of articles on this topic. This question certainly will work if the professor is not concerned with checking all of the possible answers that may be submitted. However, leaving the question open ended causes many students frustration and uncertainty in having to select an answer. A better question would include direction to a specific article by limiting the selection by date, law review, year, or author. "Find the 2004 Santa Clara Law Review article that discusses 
trademark parody." This question gives the student direction by including the date and law review as well as the indexing terms under which the article can be found either on LegalTrac or in Index to Legal Periodicals and Books.

Some might criticize this approach to writing treasure hunt questions as being "spoon feeding." But those who criticize should remember the goal of the assignment is to have the student gain hands-on experience with using a research tool to find an answer. By directing the student to a specific answer, the student gains familiarity with the research tool and gains confidence in his research skills. The idea is not to frustrate the student by hiding the ball or making the questions impossible to answer. Professors should foster the idea that research is a much-needed skill that can be mastered by the student.

\section{TREASURE HUNT LIMITATIONS}

One limitation of treasure hunt questions is that the questions typically have a short life span. It is the nature of legal publishing to frequently replace print resources, which can have a detrimental effect on the research question. Consequently if any significant time has elapsed since the initial writing of the question, it is imperative to check the questions before assigning them to determine if the question still works with the currently available print resources. In addition, students often mark the answers in the volumes as a "favor" for future researchers or circulate the answers to other students. Treasure hunt questions can also be hard on the library's collection. Seventy students pulling the same volumes create wear on the library collection. Because of these factors, there is an inherent need to replace the treasure hunt questions on a regular basis.

\section{CONTEXTUAL PROBLEMS}

The second type of research question is the contextual research problem. Contextual problems show the process for conducting legal research. The professor provides a fact pattern to the students and then takes the students step by step through the process of researching that fact pattern. Contextual problems simulate real life research. The contextual problem can be accomplished by using a new fact pattern for each step or by using one fact pattern for all of the research steps. For example, if the professor wants to show the process of finding a case, then updating that case, then looking up the statute cited in the case, and finally updating the statute, the professor can write one fact pattern that moves the researcher through each of these steps, whether as one assignment or as four individual assignments based on the one fact pattern. Teaching this process could also be accomplished 
through the use of four separate fact patterns, each fact pattern having its own assignment for one of the steps in the process.

Contextual research problems provide students with a more "real world" experience than do treasure hunt problems. The students are able to experience the type of research they will be conducting as attorneys and will learn how the pieces of the research puzzle fit together. Besides requiring the answer to the legal question posed in the problem, the professor could also require the student to submit a research log detailing his or her steps in the research process, as well as an invoice for the time spent researching. While it may be easier for the professor to write individual problems for each research step since the questions are independent from each other, the use of one fact pattern provides the students with a more realistic experience of the research process. The one fact pattern is more difficult to develop because the facts must permit the researcher to experience each step. For example, a problem that requires the student to research a statute that does not have any interpretative cases will not allow the student to conduct research in case law. If the goal of the problem was to research both statutory and case law, the problem would fail.

\section{DEVELOPING THE CONTEXTUAL PROBLEM}

To develop a contextual problem, the professor must first determine the research process he wants the students to experience. The steps of legal research vary as to whether the problem is a statutory problem or a common law problem, so the professor must select an area of law that corresponds to either statutory law or case law. For example, whether an individual qualifies as an innocent spouse under federal tax law is a statutory problem. With such an issue, the student's research can either begin in the federal statutes and then progress to interpreting case law or begin in the cases and move on to the federal statutes. However, if the student was researching whether a child is liable for the intentional tort of battery, the student would be looking for case law since the issue is a common law problem and statutes are not applicable. After deciding on the process, the research begins for the professor, who looks at the law in the selected area to find an issue for the student to research. The issue need not be a complicated one. Since the student is a beginning researcher and a novice as to the law, a basic issue will suffice. One common mistake made by authors of legal research problems and writing problems, for that matter, is the tendency to compile a problem that is too complicated due to its over-reaching cleverness for the student. Here, the familiar phrase of "keep it simple" should be followed, at least for new researchers.

Regardless of whether your research goals include statutes or not, case law will almost always be a part of the research. Therefore, researching 
in cases is a good place to get an understanding of the law in regard to the facts that precipitated the problem. The facts from the case provide the author with a foundation upon which to write the "story" of the research problem. The professor can combine the facts of two or more cases or modify the facts of a single case to create the fact pattern that will be given to the student. Modifying the facts serves a significant purpose. Beginning researchers often believe that there is a specific case exactly on point as to facts and as to law, and it is their job to find that one case. This scenario is rarely the case. Researchers are more often looking for analogous cases. Consequently, modifying the facts will help the researcher grasp the idea of looking for similar cases.

After compiling the cases and the statutes, if applicable, the professor can then narrow the question that the student will be asked to research and can begin writing the fact pattern. The writing of the fact pattern can be as straightforward as the professor wants. Sure, clever and cute fact patterns are entertaining to the student but the professor should not lose sight of the ultimate goal, to teach the process of legal research and not to win points for creativity. That being said, simple techniques can be employed to make the fact pattern engaging: name the characters in the fact pattern after historical figures, literary characters, or television characters; and use settings to correspond with those figures or characters.

One of the final aspects of developing the problem is to write the call of the question that the student will research. ${ }^{5}$ Since the professor conducted the research in the area of law, he should have a good understanding of what the law is in this area. From reading the cases, the professor has seen the issues raised in litigation and can craft an issue for the student to research. The call of the question can be one that has a definite answer for the student to find or one that is unsettled or debatable as to the facts given to the student. For a beginning researcher, unfamiliar with the law and researching, it is easier to approach a problem that has a definite answer. The student will be able to use his knowledge to conduct research that not only allows him to find an answer but to see how the research tools work together.

However, real life legal problems do not always, and in fact often do not, have definite answers. To give the student the opportunity to research a problem without a definite answer, the professor can set the problem in a jurisdiction that does not have primary, mandatory authority for the problem. The professor can instruct the student to look for mandatory authority for the problem's jurisdiction; but if none exists, the student should look for persuasive authority, often mandatory authority from another jurisdiction. The important factor is to advise the student as to whether there is mandatory authority for the jurisdiction he is researching or whether he should be looking at persuasive authority to solve the problem. These instructions will allow the novice researcher to focus on the task at hand which is to learn the steps to researching a problem. Once the student has been introduced 
to the basics of legal research, he can move on to more advanced situations where he is not told up front whether or not there is a definitive answer, but his prior experience will alert him to the possibility that there may not be an absolute answer.

The first several times a professor goes through the process of researching and writing a problem, he should leave significant time to put the problem together. In other words, these problems can take several days to compile, particularly when the professor is new to the process. The most difficult part is finding the particular area of law that will allow the professor to take the students through the steps that he wants the students to learn. As one gets more familiar with the process, it tends to get easier to construct the problems.

\section{TEST THE PROBLEM IN THE HOME LIBRARY AND IN VARIOUS FORMATS}

The author of the problem must also be familiar with the library's collection when writing the problem. If he selects a jurisdiction other than the home state of the library, the professor must make certain the library has the materials for the problem's jurisdiction and that the materials are current. Writing a statutory problem based in Arizona when the library does not have a current subscription to the Arizona statutes and the student has not yet received full access to the information on Westlaw or LexisNexis will be a disaster.

Online access brings up another point. The professor must indicate if the assignment is to be completed in paper resources, in online resources, or if it can be completed in either. The professor must test the problem in whatever format he permits the student to use for the research. If the professor wrote the problem using print resources but then either requires the student to use electronic resources or gives the student the option to use electronic resources, the professor must first conduct the research on the electronic resource to ensure that the problem works in that format. The reverse is true as well. If the professor used Westlaw or LexisNexis to research and write the problem but then requires the student to conduct his research in print or allows the student the option to conduct his research in print, the professor must make sure that the problem can be researched in print and that the library subscribes to the print resources needed for the research.

If the professor recycles the contextual problem in subsequent years, he must conduct a research check to determine if the problem still works. Just as with treasure hunt problems, the resources as well as the law can change and nullify the problem. The library print resources may have been marked with the answers or so overused that the resource literally falls open to the applicable page. In addition, students often pass down class information to 
the group of students coming behind them. These are all factors that may require the retiring of or the significant modification of a good research problem.

\title{
CONTEXTUAL PROBLEM I: "LIKE SANDS THROUGH THE HOURGLASS ..."
}

The next part of this article provides two examples of how a contextual research problem was developed. In the first example, the student is told he is a law clerk working for the professor's fictitious law firm. The student is given the fact pattern and told to research for an office memorandum whether or not the holographic will is valid.

\author{
Phillips \& Teller P.L.L.C. \\ Attorneys at Law \\ 1515 Commerce \\ Fort Worth, Texas 76102
}

TO: Law Clerk

FROM: S. G. Finkbeiner, Esquire

RE: Research State law

Please do the research for an office memorandum, based on the following problem:

After a whirlwind courtship filled with passions in the city of Santa Barbara, Beauregarde and Faith Brady were married in November 1997 and lived as husband and wife in Dallas, Texas. Beau had three grown children from a previous marriage. In February 2001, Beau, a doctor at General Hospital in Port Charles, decided that he was no longer one of the young and the restless and that the time had come to execute a will. Being somewhat frugal, Beau decided to forego hiring an attorney to draft the document. Instead, Beau wrote the following will in his own handwriting:

I, Beauregarde Brady, being of sound mind and health do hereby declare that this is my last will and testament. My loving family, if you are reading this will, then I have obviously followed the guiding light to another world. To you I bequeath the following: To the bold and the beautiful Faith, for her generous support all the days of our lives, I leave my entire estate, including all property, real and personal, minus a token amount for each of my three children. To all my children, I leave you each $\$ 1,000$ and these words of wisdom-You only have one life to live, so live each day to the fullest. 
Beau signed and dated the document and then placed it in his safe.

On June 4, 2007, Beau Brady met with a tragic death when the singleengine Cessna he was piloting to Sunset Beach crashed on takeoff. The preliminary National Transportation Safety Board investigation is looking at pilot error as the cause of the crash since investigators found Beau had worked the night shift on four consecutive days from May 31 through June 3 and was probably suffering from great fatigue. His entire family was devastated by the event. However, when the contents of the will became known, his children were outraged that they were left a pittance and their stepmother inherited the bulk of the estate. They have challenged the validity of the will, particularly since there were no witnesses and it was handwritten except for one typewritten provision, the last sentence (To all my children, I leave you each $\$ 1,000$ and these words of wisdom-You only have one life to live, so live each day to the fullest.). Is the will valid?

Research the question under Texas law. For this problem only, we are unsure in which trial court we will file. Consequently, assume all Texas Court of Appeals decisions as well as Texas Supreme Court decisions are binding.

BONUS: What daytime soap opera currently on one of the major networks is not mentioned in the problem?

\section{COMMENTS ON THE DEVELOPMENT OF THE CONTEXTUAL PROBLEM I}

First, the author determined the research steps that the problem would cover: state statutes and interpreting case law. The goal of this problem is to have the student conduct research in state statutes, update the statute, find interpreting cases, and update the cases. This problem tests the student's ability to research and update statutes, as well as the student's ability to find cases that have interpreted the relevant statute.

Next, the author looked for an area of law that is governed by state statutes and had cases interpreting the statutes. Initial research was conducted in Texas law since the home library's collection included several copies of the Texas statutes and codes. In looking through the subject areas of the Texas statutes, the author decided to look at the law of wills and found the Probate Code section concerning holographic wills. The plain language of the statute gave the impression that the law was unambiguous, but upon reading the interpretive cases, the courts have interpreted the statute quite uniquely. The interpretive cases gave rise to the issue of the validity of a handwritten will that contains some part that is not in the testator's handwriting. The author found appealing the fact that the issue would afford the student the opportunity to research specific law with, arguably, no definitive answer. Before proceeding, the author updated the statute to make sure it was still good law and updated the cases as well. 
After reading and updating the statute and cases, the author then synthesized the law from the statute and cases. This process allowed the author to determine the call of the question: whether or not a holographic will with one sentence typewritten would be probated as a valid will under Texas law. The author next wrote the fact pattern of the problem. The problem obviously needed to reference a handwritten will that contained a typewritten portion. Because the class that would be using this problem was set up as a fictitious law firm with the student acting as the firm's law clerk, it was a logical step to write the problem as if a client with the holographic will issue had walked into the firm. The problem's fact pattern required certain elements: a dead person, a holographic will with a typewritten portion, and people fighting over the validity of the will. The story was written with the main characters named after soap opera characters. The idea to incorporate the soap opera theme simply came to the author on one of her very limited creative days.

The author then tested the problem both in paper resources and on Westlaw and LexisNexis. The author uses this problem annually and retests it every year to make sure it is still valid. The date of the decedent's death is updated every year so the student does not go down the statute of limitations trail. Over the years, as the major networks added new soap operas, the titles were incorporated into the problem. Soaps that were cancelled remained in the problem! The students get a chuckle out of the problem and its pop culture references which sets them at ease for the class.

The soap opera problem is a good gauge of the student's research skills at the beginning of the semester. The Texas statute dealing with holographic wills states that a holographic will must be "wholly" in the handwriting of the testator. ${ }^{7}$ Some students end their inquiry upon reading the statutory language. Those students who delve further into the case law discover that there are several applicable cases that interpret typewritten portions of wills. The question then becomes whether the will will be probated, and if so, whether it will be probated with or without the typewritten sentence. From the cases, it seems that the court will allow the document to be probated. The student is then faced with the question of what will happen to the typewritten sentence. Students then see that there are arguments on both sides and must argue the facts.

This problem can be modified to fit other jurisdictions.

P.S. The answer to the bonus question is As the World Turns.

\section{CONTEXTUAL PROBLEM II: EDDIE'S COPYRIGHT ROYALTY DILEMMA ${ }^{8}$}

In the second example, the student is again a law clerk working in the professor's fictitious law firm. The student is given the fact pattern at the 
beginning of the semester. The fact pattern is used throughout the semester. Each week, the professor assigns a different step of the problem to research.

\author{
Phillips \& Teller P.L.L.C. \\ Attorneys at Law \\ 1515 Commerce \\ Fort Worth, Texas 76102
}

TO: Law Clerk

FROM: S. G. Finkbeiner, Esquire

RE: Class Problem

Tina Rickles has come to our law firm seeking advice for a legal situation involving her young son, Eddie. Ms. Rickles has related the following information concerning the problem: Ms. Rickles met Tom Corbett on October 14, 1999. The two shared many common interests, and soon a romantic relationship developed. The couple tried unsuccessfully for over a year to have a child. After seeing several fertility specialists, Tom and Tina conceived a child through artificial insemination using Tom's sperm and Tina's egg. They agreed that they were going to raise their child together. With Tom present, Tina gave birth to Eddie Corbett on December 30, 2002. The two were ecstatic over the birth of their child. The couple never married but did live together. Tom provided Eddie with financial support as well as paternal emotional support. Tom always referred to Eddie as his "son" whenever speaking of the child in conversation.

During the entire time of the above relationship, Tom Corbett was married to Crissy Drummond. Tom and Crissy met in 1966 and subsequently married on December 1, 1968. The couple never had children. On January 27, 1977 after years of work, Tom's novel People, Let Me Tell You About My Best Friend was published by FWT Publishing Co., a Tulsa, Oklahoma company. Tom retained all intellectual property rights to the novel. The book was a huge commercial success making it to the top of The New York Times Best Seller list and garnering many literary prizes. The work continues to sell briskly as it is often required reading in high school and undergraduate college English courses.

In April 1999, Tom and Crissy came to the realization that they had grown apart as a couple and amicably agreed that each was free to enter into other relationships. The couple never bothered to divorce.

On March 14, 2004, Tom Corbett died tragically in a single car accident when he lost control of his convertible Corvette and hit a telephone pole. Everyone was devastated by the event, particularly Tom's housekeeper, Mrs. Livingston. Since Tom's death, Crissy, Tom's widow, has been collecting 
the royalties from his book. Tina has come to us seeking help in obtaining Eddie's share of the royalties.

Note: All of the events in this problem took place in Fort Worth, Texas.

\section{Assignment 1}

Please begin researching our client Tina Rickles' case by looking for a secondary source that will help you determine the duration and renewal scheme for Tom's copyright. As you may remember, one of the places you can start your research is in secondary sources. Why? Because you may not understand enough about the issue and need that Encyclopedia Britannica background to start; or, if you do understand the area of law, you may save time by finding material where someone else has done the research for you!

REMEMBER: Your main research objective is to find primary, mandatory authority for your jurisdiction! If no mandatory authority exists, then find primary, persuasive authority.

A relevant secondary source should provide you with the citation to the federal law that answers the following question: What is the applicable federal law regarding copyright renewal of Tom Corbett's 1977 novel? Using proper citation, give the answer to this question. Your next step after using the secondary source is to go look at the primary authority since that is your ultimate goal.

\section{Assignment 2}

The firm continues to work on Tina Rickles' case. As you know, she is trying to get her son Eddie, his share, if any, of the royalties from Tom Corbett's book. Tom's widow, Crissy, claims that as Tom's widow, she is exclusively entitled to the copyright renewal.

Please research federal law and find the statute that indicates who is entitled to renewal when the author is deceased. Update the statute. Provide the proper citation to the applicable federal statute. According to the relevant case law, is Crissy's claim accurate? In proper citation format, provide one case that is mandatory authority and supports your explanation.

\section{Assignment 3}

We now know who is entitled to the renewal term based on the nondiscretionary hierarchy set forth by statute. We need to begin our research into whether or not Eddie will fall within the definition of "child." Two years ago, an attorney with our firm conducted research on this topic. He had pulled all of the federal cases that had been assigned the topic and key number that includes that point of law regarding transfer of copyright due to death and children. He claims to have put all of the cases he found in a file folder. Unfortunately, the attorney is not known for his organization, and when we 
sent him to retrieve the file, the only case in the folder was Fitch v. Shubert, 20 F. Supp. 314 (S.D.N.Y. 1938). The attorney does remember some pertinent information - the topic and key number for headnote \#2 has been reclassified. The new topic and key number given this headnote is the topic and key number assigned to the point of law that we are researching.

Please find all of the federal cases that have been assigned a headnote with the new topic and key number.

1. What is the new topic and key number?

2. How many federal cases have been assigned this topic and key number?

3. Which of the federal cases that have been assigned this topic and key number will be most useful to us as to the "child" issue? Use proper citation form.

\section{Assignment 4}

NEW FACTS: Prior to Tom's death and under the original term of the copyright, Tom granted a license to Hollywood producer George Templeton of Hill Country Productions to make a motion picture based on Tom's novel. Tom even agreed to assign the motion picture rights to Templeton for the renewal period. The movie version of People, Let Me Tell You About My Best Friend was a big success and included a cast of big name actors. The film was nominated for several top prizes and made its international debut at the Cannes Film Festival. As we know, Tom died before filing for the renewal of the copyright in the novel.

I would like you to research whether or not under the renewal term performances of the motion picture or sales of the DVD are infringements of the copyright in the underlying work. Please find the case that is mandatory authority for our jurisdiction regarding this issue.

There is a catch-the firm is in a dispute with both Westlaw and Lexis regarding our contracts for those services. We are unable to use either service until the dispute is resolved. Consequently, you may only use the appropriate paper digest to find the case in question. Use either the topic analysis method or the descriptive word method to find the relevant topic and appropriate key number in the digest.

Please identify the case using proper citation and provide the topic and key number under which you found the case.

\section{Assignment 5}

After reading the cases we have found so far, it seems that the controlling question as to whether Eddie will be considered a child under the renewal section is whether under state law Eddie is an heir of Tom entitled to claim under intestacy statutes. Please research state law and determine the best 
way for Eddie to establish his paternal parentage. Begin your research in statutes and also look at applicable case law. Often times, the text of one statute refers to another statute. Make sure you look at all of the applicable statutes.

What is the proper citation to the Texas intestacy statute in question? Provide a brief narrative (no more than a page) setting forth your legal strategy for establishing Eddie's paternal parentage. Please include the citations to two Texas state cases supporting your position.

\section{Assignment 6}

Please anticipate Crissy's best argument against finding Eddie to be the child of Tom under Texas state law. I am certain that there is a code provision that provides Crissy with a good argument against finding Tom to be Eddie's father due to the unique nature of Eddie's conception. I seem to recall that there is also a Texas case that does not allow the above provision to completely shut the door on our case-it gives us hope that the statute is not strictly interpreted.

Please research this area for me. There is one catch-Tina is unwilling to pay for any electronic research charges; therefore, you will not be able to use Westlaw or Lexis for this assignment as our firm will not absorb the cost as overhead. Remember subsequent history if applicable.

Provide me with the proper citation of the statute/code and case I am seeking.

\section{Assignment 7}

As you may know, the federal statute that provides the nondiscretionary hierarchy for copyright renewal is silent as to the exact proportion of the renewal interest that vests in each eligible party. Some cases have interpreted the statute to give disproportionate shares, meaning the surviving spouse gets fifty percent undivided interest and the children take the remaining fifty percent in equal shares. Other courts have held that the widow and surviving children share equally.

It appears in our problem that proportioning is not an issue since we believe Eddie is an only child. However, Tina has just called our office and indicated that there is a rumor that Tom has another child from a marriage that occurred before Tom married Crissy. This marriage ended in divorce.

I would like you to conduct some legislative history research to see if Congress addressed the issue of proportioning the renewal interest in any of the documents associated with the Sonny Bono Copyright Term Extension Act of 1998.

Please print off the summary of the legislative history for the Sonny Bono Copyright Term Extension Act of 1998 (go to the record marked legislative 
history, hit enter, and then print this document) and submit a copy of the first page (title page) of the House Report listed under the 105th Congress from the microfiche version of the report.

\section{Assignment 8}

While we know that Tom's book fell under the automatic renewal provision for copyright, I would appreciate it if you would find a copy of the copyright renewal registration form. We need to keep a copy in our file. Make sure you get the renewal form for works registered during their original term and the necessary form for works that were not registered during their original term. (STUDENTS: You may submit these forms from either a print or electronic source.)

Due to your excellent work on her case, Tina has decided to have our firm draw up her will. Please find me a form for a Texas will. Don't bother to retype it, just photocopy it, and I'll fill in the blanks. I appreciate you doing this work for me and will remember you when it comes to voting on extending offers to law clerks. (STUDENTS: After finding the form in hard copy, please also find it from an electronic source other than Lexis or Westlaw and print it out.)

\section{Assignment 9}

Thanks for finding the copyright renewal forms and the Texas will forms. I need a little more research before the partners vote on which clerks to whom they will offer summer associate positions.

FWT Publishing Co., as holder of the royalties generated from Tom's book, has filed an interpleader action to determine its payment obligations.

I need to know the federal court rule for interpleader (not statutory interpleader) and if the appropriate diversity of citizenship requirement is met under rule interpleader (not statutory interpleader). It may help to look at a practice guide to obtain this information.

1. Please provide me with the proper citation to the federal court rule for interpleader.

2. What is the necessary diversity of citizenship requirement for federal court rule interpleader, and is it met here?

3. Also, if we lose at the trial level, I plan on appealing to the court of appeals. I need you to tell me how many days I have to file the notice of appeal after the judgment or order is entered. Provide me with the answer and the proper citation to the rule. In counting the days that I have to file the notice of appeals, do I count Saturdays and Sundays, and assuming Columbus Day falls within the time period, does it count? Provide me with the answers and the proper citation to the rules. 


\section{COMMENTS ON THE DEVELOPMENT \\ OF THE CONTEXTUAL PROBLEM II}

This problem was certainly more challenging to develop than the soap opera problem. First, the author determined the research steps the problem would cover: secondary sources, federal statutes and interpretative cases, West's topic and key numbers, paper digests, state statutes and interpretive cases, legislative history, form books, and court rules. Each step in the research process would be discussed in class prior to the particular assignment being given to the student.

Next, the author looked for an area of law that is governed by both federal law and state law, particularly statutory law that has interpretive cases. Through experience, the author knows that there are certain areas of federal law that look to state law to resolve specific controversies. For example, bankruptcy law and federal tax law often look to state law to determine whether certain property is community property or not. To find these areas of intersecting law, the author will conduct an electronic search for federal case law using one of the following searches: "federal w/5 law w/5 looks w/5 state w/5 law," "refer! w/5 "state law," or "state law" w/5 control!"

After running the search, the author then skims through the results to determine if any of the resulting cases include both federal and state statutory law. If so, and the topic appears promising, the author then begins researching both the federal issue and the state issue in the case. The author looks at the interpretive cases in particular and notes the jurisdiction of the cases to determine which jurisdictions will have primary authority and which will have persuasive authority.

When conducting the research for this problem, the author found at least one federal case dealing with the nondiscretionary hierarchy of persons entitled to copyright renewal when the author is deceased. The case involved the illegitimate child of the author suing the author's widow for his share in the copyright. In the case, the court looked to the state inheritance laws to determine if the child falls within the federal copyright statute for renewal. Because the federal case was from the United States Supreme Court, the author knew this case would be controlling in all jurisdictions. The author then turned to research the state law issue. Again, the author selected to begin the state law research in Texas since the home library's collection contains plenty of Texas resources. The Texas inheritance statute referenced the Texas Family Code in determining whether a child is the child of his biological father. The Texas Family Code provides the means for establishing paternity. The interpretative cases further provided the author with the fact situations that had been adjudicated under the statutes. Again, before proceeding further, the author updated all relevant statutes and the cases as well. 
After reading and updating the statute and cases, the author then synthesized the law from the statute and cases. This process allowed the author to determine the call of the question: whether or not under federal and state law, a child born out-of-wedlock is entitled to a share of the copyright that was renewed after the author/father's death. The author next wrote the fact pattern of the problem by first listing the required elements of the problem: a dead author, the author's widow, the author's child born outside of a marriage, and circumstances of the conception that put the child's paternity in question. The author penned the story in draft form and then decided to name the characters after a 1960 s movie and television show, The Courtship of Eddie's Fatber?

Because the author was using this fact pattern for multiple assignments, the author then looked at each step of the research process and created the call of the question for each step/assignment. Copyright law is actually quite a complicated area of the law. Consequently, the author created the first assignment so that the student began his research in secondary sources in order to obtain an overview of the law of copyright. The assignment asked the student to identify a specific federal copyright statute. The second assignment asked the student to look up that federal statute, update the law, and provide his interpretation of the law supported by a case that is mandatory authority. The third assignment introduces the student to expanding his case law research through the West topic and key number. The student can conduct this assignment in paper or on Westlaw. The fourth assignment gives the student new facts and asks the student to find a case that will answer a specific question; however, the student is not permitted to use electronic resources. In the fifth assignment, the student researches state statutory law and corresponding state case law. The next assignment takes the student from the Texas Probate Code to the Texas Family Code. Again, the student is unable to use electronic research and must find interpretative case law along with the statutory section.

The above assignments essentially get the student through the substantive legal aspects of the fact pattern. The seventh assignment provides the student with the experience of retrieving a document from a legislative history of one of the recent federal copyright laws. In the ninth assignment, the student is introduced to form books and must retrieve a form related to copyright as well as a form for a state will. These individual assignments permit adding new facts when necessary! The final assignment covers court rules and, again, introduces new facts tangentially related to the problem. These individual assignments taken from one fact pattern allow the student to follow the research process in a step-by-step manner.

During and after the creation of each assignment, the author tested each assignment in paper and on Westlaw and LexisNexis if the problem allowed the student to use the electronic resources. In the event the author uses the problem in subsequent years, she will certainly check to make sure the 
law, as well as the resources, are still valid. Typically, it is easy to make adjustments to a fact pattern when there are changes in the substantive law.

\section{CONCLUSION}

Developing good legal research problems takes planning and patience. The professor should leave sufficient time to properly consider the research goals that he wants to impart to the student, as well as sufficient time to determine the appropriate area of law to meet these goals. Our responsibility as professors is to introduce the student to the standard legal research techniques that are commonly known by well-informed attorneys. In doing so, we must provide the students with a research experience that will allow them to learn the research process needed for the practice of law. Research is a skill that must be learned by doing. Professors should not expect students to learn to properly research on their own or figure it out after graduation. We have an obligation to prepare our students for the practice of law, of which research is a critical component. As such, professors must create research problems that will lead the students through the research steps that they need to master. These problems should be well planned and tested with the goal to teach the students research. The skill of writing the research problem is one that any professor can master. It simply takes familiarity and an attention to a systematic process whose end result is to impart to the students the skill of conducting research.

\section{NOTES}

1. See e.g. Dixon Ticonderoga Co. v. Est. O'Connor, 248 F.3d 151 (3d Cir. 2001); Wash. Elec. Coop., Inc. v. Mass. Mun. Wholesale Elec. Co., 894 F. Supp. 777 (D. Vt. 1995); TCW/Camil Holding LLC v. Fox Horan E Camerini LLP, 330 B.R. 117 (D. Del. 2005); Smith v. Lewis, 530 P.2d 589 (Cal. 1975), overnled on another point; Janik v. Rudy, Exelrod E Zieff, 14 Cal. Rptr. 3d 751 (App. 1 Dist. 2004); Stanley v. Richmond, 41 Cal. Rptr. 2d 768 (App. 4 Dist. 2003); Lopez v. Clifford L. Offs., P.C., 841 N.E.2d 465 (Ill. App. 1 Dist. 2005); Clary v. Lite Mach. Corp., 850 N.E.2d 423 (Ind. App. 2006); Kempf v. Magida, 832 N.Y.S.2d 47 (App. Div. 2 Dept. 2007); Shopsinv. Siben E Siben, 702 N.Y.S.2d 610 (App. Div. 2 Dept. 2000); McCoy v. Tepper, 690 N.Y.S.2d 678 (App. Div. 2 Dept. 1999); Copeland Lumber Yards, Inc. v. Kincaid, 684 P.2d 13 (Or. App. 1984); Fiorentino v. Rapoport, 693 A.2d 208 (Pa. Super. 1997); Collas v. Gamick, 624 A.2d 117 (Pa. Super. 1993).

2. Intl. Shoe Co. v. Wash., 326 U.S. 310 (1945).

3. Metzgerv. Silverman, 133 Cal. Rptr. 355, 361-362 (Super. App. Dept. 1976) (citing Smith v. Lewis, 530 P.2d 589 (Cal. 1975), overmled on another point).

4. The treasure hunt problem is the basis of Nancy P. Johnson \& Susan T. Phillips, Legal Research Exercises, Following the Bluebook: A Uniform System of Citation (10th ed., Thomson West 2008). Recent editions have attempted to combine the treasure hunt questions with the process of conducting legal research.

5. The "call of the question" is what the question asks the students to do or what issues the students should address. For example, the call of the question could ask the student to research how a court would 
rule on a particular matter, to determine what the defendant's best argument is, or to research the current law in a given area.

6. Problem reprinted with permission from Susan T. Phillips. Copyright 2008 by Susan T. Phillips.

7. Tex. Prob. Code Ann. $\$ 60$ (2003).

8. Problem reprinted with permission from Susan T. Phillips. Copyright 2008 by Susan T. Phillips.

9. Much to the author's chagrin, none of the students in the research class had any clue that the characters and setting of the research problem were taken from The Courtship of Eddie's Father. 